\title{
PERANCANGAN APLIKASI SISTEM PAKAR PENILAIAN KARYAWAN PADA CV MANDIRI BERBASIS JAVA NETBEANS
}

\author{
Hanif Maliki Akbar', Bramantara Yudha², Dona Katarina ${ }^{3}$ \\ ${ }^{1,2,3}$ Universitas Indraprasta PGRI \\ Jl.Raya Tengah No.80, RT.6/RW.1, Gedong, Kec. Pasar Rebo, Jakarta Timur 13760 \\ $\underline{{ }^{1} \text { hanifmaliki16@gmail.com, }{ }^{2} \text { bramantarayudha@gmail.com, }{ }^{3} \text { dona.katrin@gmail.com }}$
}

\begin{abstract}
ABSTRAK
Di perusahaan manapun evaluasi penilaian karyawan tidak dapat dipisahkan, dalam mengevaluasi kinerja setiap karyawan dilakukan pada periode waktu tertentu yang ditetapkan perusahaan. Hal ini dilakukan untuk melihat bagaimana karyawan bekerja dan memenuhi standar perusahaan, sehingga Anda dapat melakukan koreksi jika terjadi kesalahan atau penyimpangan. Tujuan dari penelitian adalah merancang sistem aplikasi pakar untuk penilaian karyawan dan pimpinan pada CV Mandiri, untuk membantu dalam pengolahan data penilaian terhadap kinerja karyawan dan pimpiminan yang sebelumnya masih menggunakan cara penilaian manual berupa catatan kertas dan microsoft excel. Metode penelitian yang digunakan yaitu Grounded Research, penelitian yang berdasarkan kepada fakta dan menggunakan analisis perbandingan, dan sumber data yang didapat pada penelitian ini yaitu dengan data primer yang diperoleh dengan pengamatan dan penelusuran langsung terhadap kinerja karyawan dan pimpinan di CV Mandiri, serta data sekunder yang didapat dengan cara melakukan wawancara yang mendalam terhadap informan. Dari penelitian yang telah dilakukan ini menghasilakan sebuah aplikasi pakar penilaian yang dapat memudahkan dan membantu dalam melakukan proses kegiatan penilaian kepada para pekerja di CV Mandiri yang berkaitan dengan pengolahan data nilai dan laporan penilaian sehingga cara penginputan, proses penilaian dan pembuatan laporan dilakukan secara tersistem dan terkomputerisasi yang terhubung dengan database dan dapat meminimalisir kesalahan-kesalahan data yang diakibatkan oleh human error.
\end{abstract}

Kata Kunci: Perancangan, Sistem Pakar, Penilaian, Kinerja Karyawan.

\begin{abstract}
In any company, employee appraisal evaluation cannot be separated. In evaluating the performance of each employee, it is carried out at a certain time period determined by the company. This is done to see how employees work and meet company standards, so that you can make corrections if errors or irregularities occur. The purpose of this research is to design an expert application system for evaluating employees and leaders at CV Mandiri, to assist in processing the assessment data on the performance of employees and leaders who previously still used manual assessment methods in the form of paper notes and Microsoft Excel. The research method used is Grounded Research, research based on facts and using comparative analysis, and the source of the data obtained in this study is primary data obtained by direct observation and tracking of the performance of employees and leaders at CV Mandiri, as well as secondary data obtained from obtained by conducting in-depth interviews with informants. From the research that has been done, this results in an expert appraisal application that can facilitate and assist in carrying out the process of evaluating activities for workers at CV Mandiri related to processing value data and assessment reports so that the input, assessment process and report generation are carried out in a systematic and computerized manner. which is connected to the database and can minimize data errors caused by human error.
\end{abstract}

Key Word: Design, Expert System, Assessment, Employee Performance.

\section{PENDAHULUAN}

CV Mandiri adalah suatu badan usaha yang bergerak pada bidang kontraktor. memiliki permasalahan tersendiri dalam penilaian kinerja, yaitu belum adanya pengholahan data secara sistematis untuk penilaian para pegawai baik itu karyawan maupun pimpinannya. Dan belum efektifnya penilaian yang ada berupa dengan cara manual pencatatan kertas dan hanya mengukur dengan satu indikator penilaian yaitu absensi yang diolah menggunakan aplikasi Microsoft Excel. meskipun CV Mandiri tersebut menggunakan teknologi komputer dalam berbagai kegiatannya, namun untuk penggunaannya masih sangat kurang dimanfaatkan, penginputan data penilaian dan juga pembuatan laporan dengan secara manual yang menyebabkan pembuatan laporan data penilaian tidak bisa dilakukan dengan cepat, sehingga waktu yang ada menjadi tidak efektif serta tidak efesien.

Berdasarkan pada uraian permasalahan tersebut, peneliti menemukan solusi pemecahan permasalahan yang terjadi untuk mengembangkan suatu sistem, melalui sistem pakar penilaian 
menjadi lebih efisien dan lebih efektif khususnya di CV Mandiri berbasis java netbeans. Dengan dibuatnya sistem ini diharapkan bisa memudahkan perusahaan dalam mengelola data supaya lebih cepat dalam ketepatan pengolahan data serta dapat meningkatkan keakuratan data penilaian kinerja kepada pegawai diperusahaan tersebut.

Sistem adalah serangkaian dua atau lebih komponen yang saling terkait dan berinteraksi untuk mencapai suatu tujuan. Sistem adalah rangkaian dari dua atau lebih komponen yang saling bergantung dan berinteraksi untuk mencapai suatu tujuan. Sistem pada hakekatnya adalah sekelompok elemen yang berkaitan erat yang bekerja sama untuk mencapai suatu tujuan tertentu (Romney, 2011). Perancangan sistem adalah serangkaian kegiatan yang merinci dalam pengoperasian sistem. Hal ini bertujuan untuk menciptakan produk perangkat lunak yang memenuhi kebutuhan pengguna (Satzinger, 2012)

Tujuan dari penelitian ini adalah untuk merancang suatu sistem yang sistematis dan terkomputerisasi dengan aplikasi berbasis java serta dapat mengidentifikasikan masalah yang ada pada sistem pengolahan data yang masih menggunakan cara konvensional dengan pendataan kertas dan pengolahan data pada Microsoft Office Excel menjadi sistem yang menggunakan aplikasi tersendiri yang terhubung dengan database. (Sukamto, 2015) Sistem basis data adalah sistem komputer yang tujuan utamanya adalah untuk menyimpan data atau informasi yang telah diproses dan membuat atau menyiapkan data dapat tersedia pada saat dibutuhkan. (Indrajani, 2015) Basis data adalah pengumpulan data yang relevan secara logis dan interpretasi data yang dirancang untuk membantu suatu organisasi untuk menemukan data yang mereka butuhkan. MySQL adalah sistem manajemen database SQL open source yang paling populer saat ini. Sistem database MySQL mendukung banyak fitur seperti multithreaded, multiuser, SQL DBMS (Madcoms, 2016).

Java dibuat oleh tim yang dipimpin oleh Patrick Naughton dan James Gosling pada proyek Code Green Sun Microsystems, dengan tujuan menciptakan bahasa komputer sederhana yang dapat berjalan pada perangkat sederhana tanpa terikat pada arsitektur tertentu, awalnya disebut oak. Namun, karena Oak sendiri adalah nama bahasa pemrograman komputer yang ada, Sun mengubahnya menjadi Java. Maka sun telah meluncurkan browser dari Java yang disebut hot java, yang dapat menjalankan applet (Suyanto, 2015). Netbeans IDE adalah open source integrated development environment (IDE) yang seluruhnya ditulis dalam bahasa pemrograman
Java menggunakan platform Netbeans. Netbeans IDE mendukung pengembangan semua jenis aplikasi Java (J2SE, Web, EJB, dan aplikasi seluler). Fitur lainnya adalah sistem proyek berbasis Ant, pengujian, kontrol versi, dan refactoring. Netbeans adalah sebuah aplikasi integrated development environment (IDE) yang menggunakan bahasa pemrograman Java milik Sun Microsystems yang berjalan pada Swing (Nofriadi, 2015).

Adapun manfaat dari penelitian ini adalah dengan dibuatnya sistem penilaian ini diharapkan dapat memudahkan sistem penilaian kinerja karyawan ataupun pimpinan dalam menginput data, menyimpan data dan membuat laporan. Pada sistem aplikasi ini sudah tidak perlu lagi mencatat dengan cara manual dan tidak perlu mengolah data melalui Microsoft Office Excel, tetapi hanya dengan menginput data kedalam database melalui sistem aplikasi ini sehingga akan mempermudah dan memangkas waktu dalam pengerjaanya. (Sihombing, S., Gultom, R. S., 2015) penilaian kinerja merupakan suatu fungsi dari motifasi dan kemampuan. Untuk menyelesaikan tugas atau pekerjaan seseorang sepatutnya memiliki derajat kesediaan dan tingkat kemampuan tertentu. (Ainnisya, R. N., \& Susilowati, 2018) bahwa banyak manfaat yang didapat dari penlaian kinerja, yaitu :

1. Meningkatkan kinerja

Dengan adanya penilaian, baik pimpinan ataupun karyawan dapat memperoleh umpan balik satu sama lain dan mereka dapat memperbaiki pekerjaannya atau prestasinya.

2. Memberi kesempatan kerja yang adil

Penilaian yang akurat memastikan bahwa karyawan memiliki kesempatan untuk melakukan pekerjaan mereka sesuai dengan kemampuan mereka.

3. Kebutuhan pelatihan dan pengembangan Melalui penilaian kinerja, karyawan yang memiliki kemampuan rendah dapat segera teratasi dengan adanya program pelatihan untuk meningkatkan kemampuan mereka lebih lanjut.

\section{METODE PENELITIAN}

Metode penelitian yang digunakan dalam penelitian ini adalah metode Grounded Research yaitu suatu metode penelitian yang berdasarkan kepada fakta dan menggunakan analisis perbandingan.

Metode pengumpulan data yang dilakukan untuk mendapatkan data dan informasi untuk mendukung penyempurnaan hasil dari penelitian ini yaitu :

1. Survey Lapangan, dengan melakukan studi bedasarkan data primer dan data sekunder dari 
instansi/perusahaan yang menjadi tempat untuk diteliti yaitu di CV Mandiri Dramaga Bogor dengan cara mengadakan :

a. Observasi

Observasi atau pengamatan dilakukan untuk memahami sistem yang sedang berjalan untuk mendapatkan kesimpulan dari masalah yang bertujuan untuk perancangan suatu sistem. Pengamatan ini dilakukan pada bulan April 2021 sampai Juli 2021, bertempat di CV. Mandiri Dramaga Bogor. Penulis mengamati sistem penilaian pegawai di CV Mandiri dan meninjau langsung tentang bagaimana proses penilaian terhadap karyawan dan pimpinan sehingga penulis dapat menyimpulkan masalah-masalah yang terjadi untuk merancang sistem.

b. Wawancara

Pada tahap awal wawancara ini dimulai dengan meminta izin kepada Bapak Iskandarsyah selaku direktur utama CV Mandiri tersebut untuk melakukan penelitian dan bertanya secara langsung kepada beliau mengenai prosedur dan langkah-langkah mengenai kondisi sistem yang berjalan dan penulis juga meminta izin untuk bertanya secara langsung kepada beberapa karyawannya guna untuk mendapatkan informasi tambahan mengenai hal-hal yang dibutuhkan dalam proses penelitian.

2. Studi Kepustakaan, dengan melakukan studi berdasarkan refrensi dan diskusi pemahaman dari studi kasus yang diangkat baik dengan dosen pembimbing, pihak perusahaan dan dengan orang yang berkompeten pada studi kasus ini. Penulis juga melakukan studi dari berbagai buku, jurnal, serta artikel di internet yang memuat informasi yang diperlukan.

Langkah-langkah pengembangan sistem disini penulis menggunakan pemodelan waterfall, pada proses waterfall ini ditunjukkan metode pengembangan dimana pengembang aplikasi diharuskan mengikuti langkah-langkah sebagai berikut :

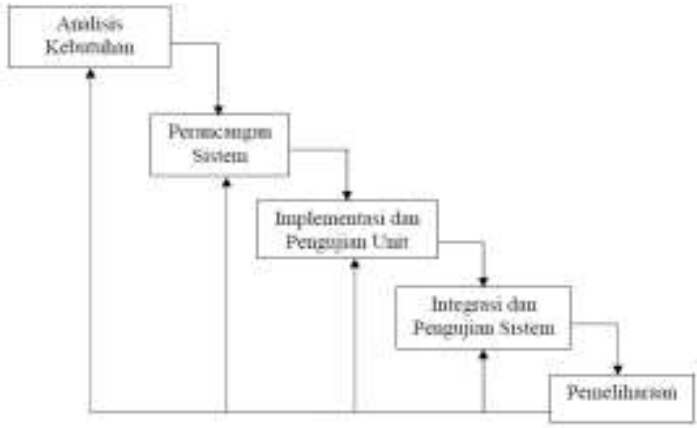

Gambar 1. Metode Waterfall

\section{HASIL DAN PEMBAHASAN}

\section{Analisis Permasalahan}

Hasil dari penelitian pada CV Mandiri ini yang nantinya akan dirancang suatu sistem pakar dengan memanfaatkan teknologi komputer yang sedang berkembang saat ini, jadi proses penginputan data, pencarian data, dan perubahan data karyawan dan pimpinan tidak menggunakan cara manual lagi, sehingga proses yang dilakukan dapat menjadi lebih cepat, tepat, akurat serta menjadi lebih efektif dan efisien dalam pengerjaanya. Dikarenakan sistem ada dan yang digunakan belum terkomputerisasi secara sistematis maka penulis merancang alur program untuk sistem pakar sehingga mempermudah dalam penyimpanan data dan pencarian data, sehingga tidak menggunakan cara konvensional dengan media kertas lagi serta dapat membuat sistem yang mudah dipahami oleh setiap pengguna agar dapat digunakan pada sistem aplikasi pakar penilaian karyawan.

\section{Alternatif Penyelesaian Masalah}

Berdasarkan masalah - masalah yang dihadapi dalam penilaian karyawan pada CV Mandiri, maka penulis memberikan alternatif masalah tersebut yaitu penulis membuat sistem pakar penilaian karyawan yang berguna untuk mengetahui tingkat kinerja karyawan. (Wibawanto, 2017) Flowchart adalah suatu bagan dengan simbol-simbol tertentu yang menggambarkan urutan proses secara mendetail dan hubungan antara suatu proses (intruksi) dengan proses lainnya dalam suatu program. Flowchart merupakan metode untuk menggambarkan tahap-tahap pemecahan masalah dengan merepresentasikan simbol-simbol tertentu yang mudah dimengerti, mudah digunakan dan standar.

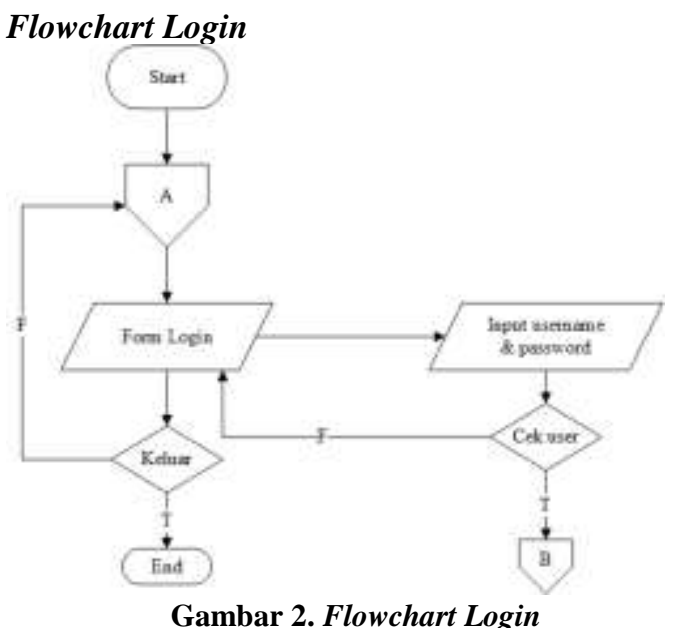

Pada gambar diatas adalah flowchart pada form login program aplikasi sistem pakar penilaian karyawan, yang dimulai dari proses admin memulai program hingga menginputin hak akses aplikasi atau username dan password. 


\section{Flowchart Menu Utama}

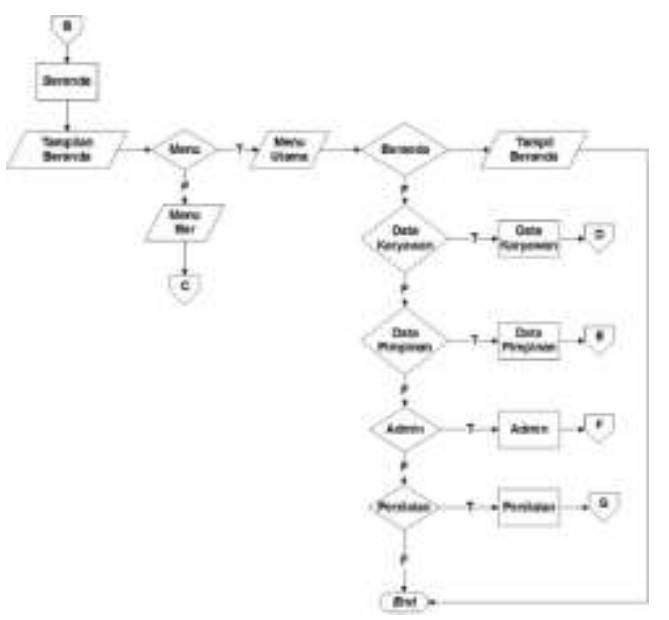

Gambar 3. Flowchart Menu Utama

Pada gambar diatas adalah flowchart pada form/tampilan menu program aplikasi sistem pakar penilaian yaitu menampilkan tampilan menu utama dan menu bar, jika ingin memilih menu utama maka akan opsi menu yang ditampilkan yaitu data karyawan, data pimpinan, admin, dan penilaian.

\section{Flowchart Menubar}

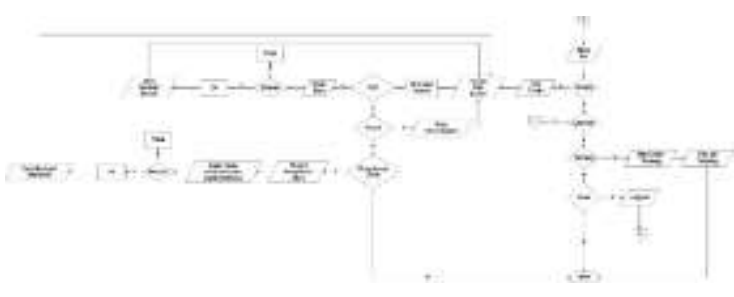

Gambar 4. Flowchart Menubar 1

Pada gambar diatas ini yaitu flowchart dari menu bar, dimana jika admin memilih bagian menu bar akan tertera empat menu bar yaitu: profile, laporan, tentang dan akun.

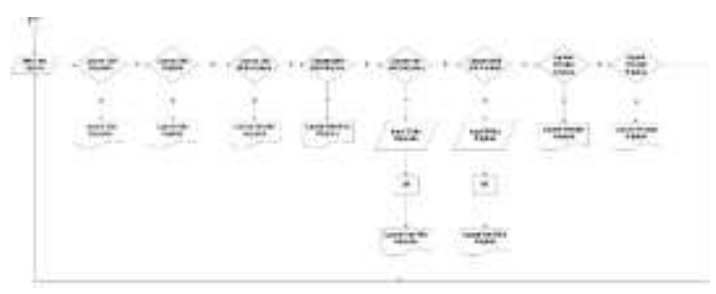

Gambar 5. Flowchart Menubar 2

Pada gambar diatas ini yaitu flowchart lanjutan dari alur sebelumnya, pada alur ini akan menunjukan alur dimana jika admin memilih menu bar laporan maka akan tertera alur untuk proses pembuatan laporan. Jika admin akan memilih menu bar laporan data karyawan maka akan tampil laporan data karyawan dan seterusnya.

\section{Flowchart Data Karyawan}

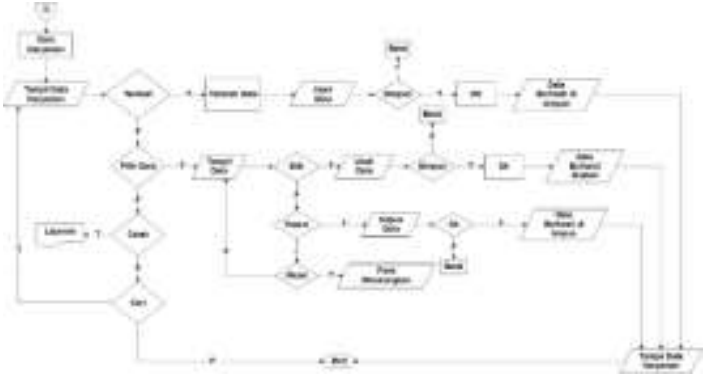

Gambar 6. Flowchart Data Karyawan

Pada gambar diatas yitu flowchart dari alur menu data karyawan, dimana pada alur ini akan mengambarkan proses penginputan dan penyimpanan data karyawan serta beberapa aksi yang dapat dilakukan pada data seperti ubah dan hapus data.

\section{Flowchart Penilaian}

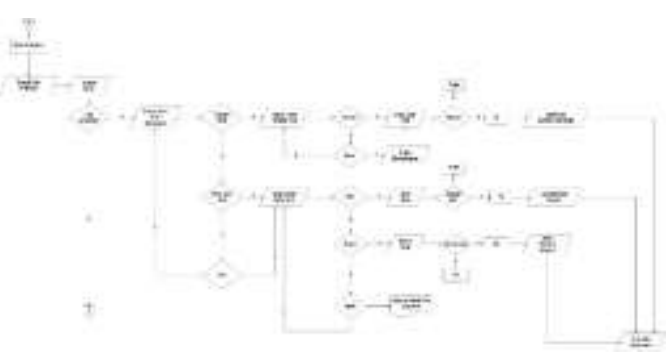

Gambar 7. Flowchart Penilaian 1

Pada gambar diatas adalah flowchart dari penilaian, dimana jika admin memilih menu penilaian pada menu utama akan tampil halaman penilaian yang menampilkan tabbed menu penilaian karyawan dan penilaian pimpinan. Pada gambar ini, akan membahas alur pada bagian penilaian karyawan dari mulai tampil data nilai, proses penilaian sampai penyimpanan data nilai yang telah dilakukan.

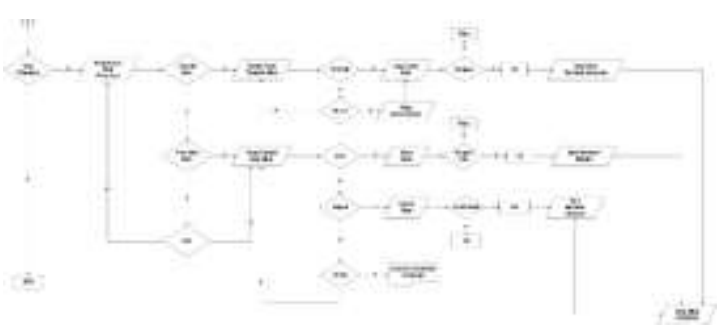

Gambar 8. Flowchart Penilaian 2

Pada gambar diatas adalah lanjutan dari flowchart penilaian sebelumnya, dimana pada gambar ini akan lebih menggambarkan alur dari penilaian pimpinan mulai dari tampil data nilai, proses penilaian pimpinan, hingga penyimpanan data nilai yang telah dilakukan serta pembuatan laporan.

\section{Tampilan Layar Login}




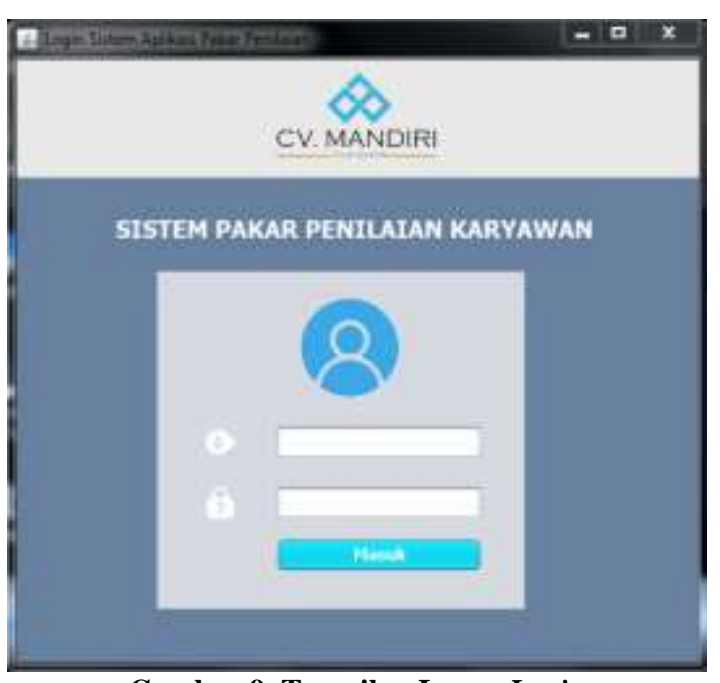

Gambar 9. Tampilan Layar Login

Pada tampilan layar login pengguna akan dihadapkankan untuk mengisi kolom username dan password yang telah di sediakan.

\section{Tampilan Layar Menu Utama}

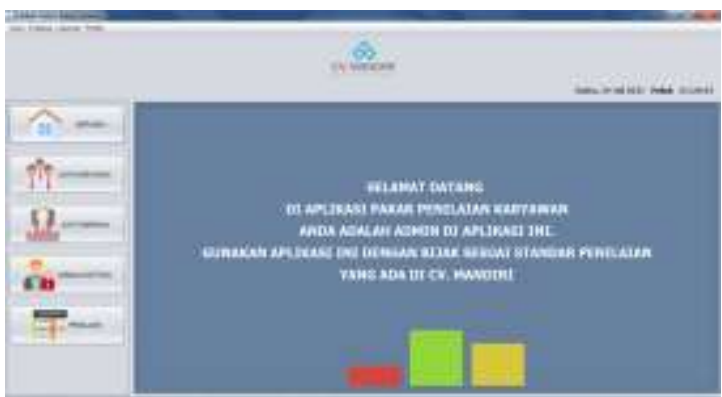

Gambar 10. Tampilan Layar Menu Utama

Pada tampilan layar menu utama pada sistem aplikasi pakar penilaian karyawan pada cv mandiri berbasis java netbeans, terdapat 4 menubar yaitu akun, tentang, laporan, dan profile. Pada tampilan ini juga terdapat menu utama yaitu data karyawan, data pimpinan, data admin, dan data penilaian.

\section{Tampilan Layar Data Karyawan}

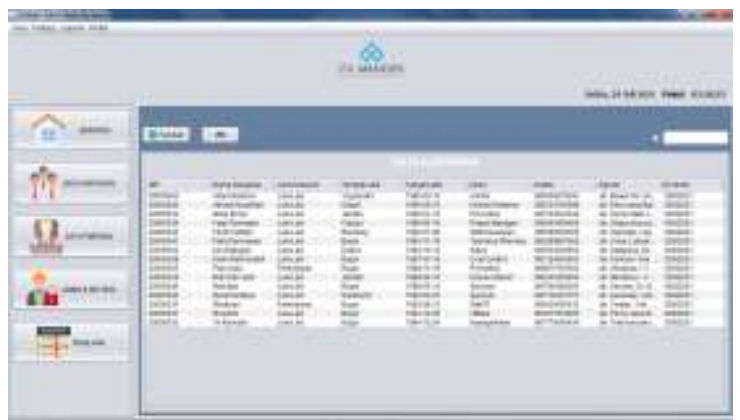

Gambar11. Tampilan Layar Data Karyawan

Pada gambar diatas terdapat tampilan menu data karyawan, dimana pada tampilan ini admin dapat melihat seluruh data karyawan yang telah diinput ke dalam aplikasi. Dan juga pada tampilan ini admin dapat melakukan penambahan data maupun hapus dan edit data karyawan, serta dapat juga untuk mencetak laporan data karyawan.

\section{Tampilan Layar Data Penilaian}

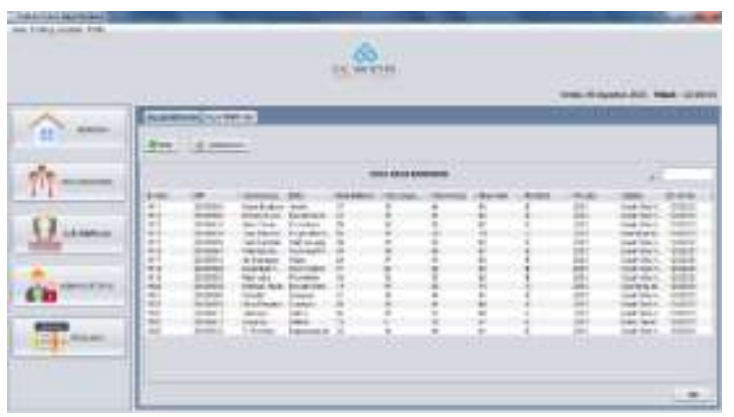

Gambar 12. Tampilan Layar Data Penilaian

Pada tampilan gambar diatas terdapat tampilan menu data peniliaian, pada tampilan ini adalah proses dari sistem pada aplikasi ini yang akan mengolah data nilai karyawan dan pimpinan.

\section{Tampilan Layar Proses Penilaian}

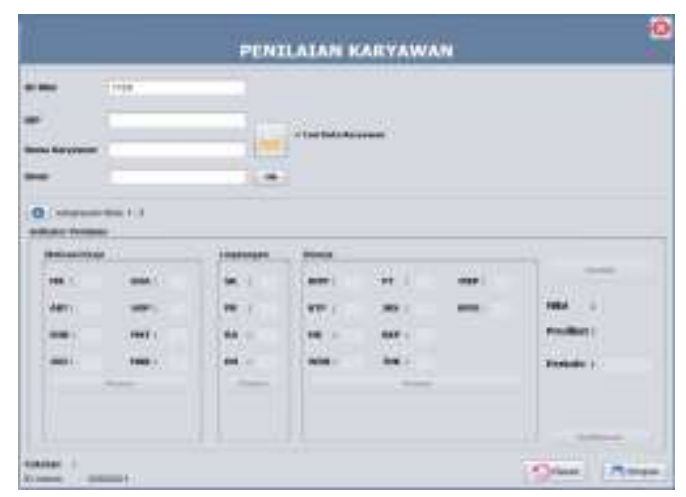

Gambar 13. Tampilan Layar Proses Penilaian

Pada tampilan gambar diatas terdapat tampilan proses data nilai karyawan, dimana tampilan ini adalah untuk memproses nilai akan diberikan kepada karyawan yang telah dipilih dengan mengisi nilai pada indikator penilian yang telah tersedia.

\section{Tampilan Detail Data Nilai Karyawan}

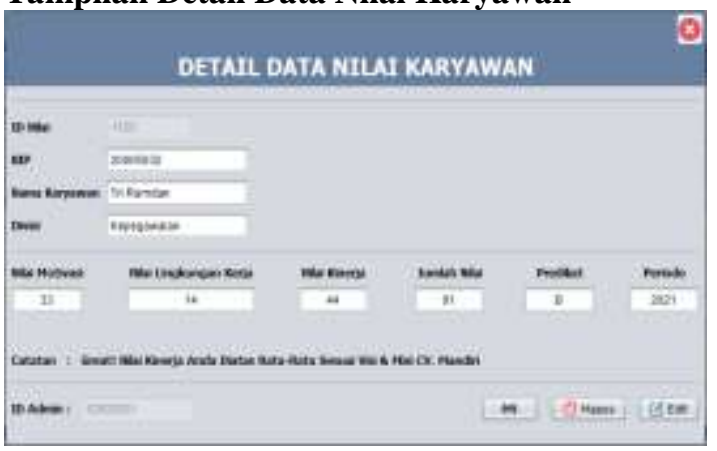

Gambar 14. Tampilan Layar Detail Data Nilai Karyawan 


\section{Tampilan Laporan Data Nilai Karyawan}

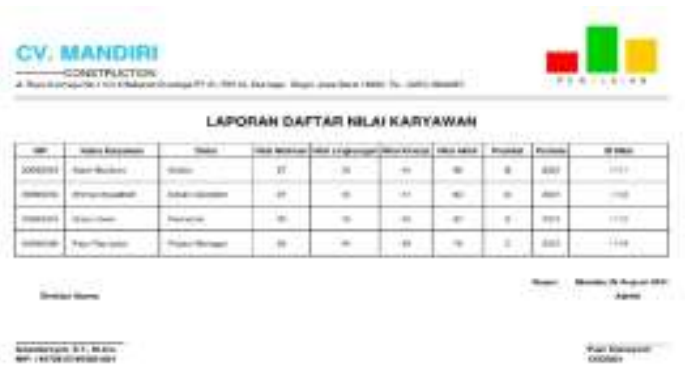

Gambar 15. Tampilan Layar Laporan Data Nilai Karyawan

Pada tampilan gambar diatas terdapat tampilan laporan data nilai karyawan, dimana tampilan ini akan menampilkan laporan data nilai karyawan yang telah diproses dan dihitung.

\section{Tampilah Laporan Hasil Nilai Karyawan}
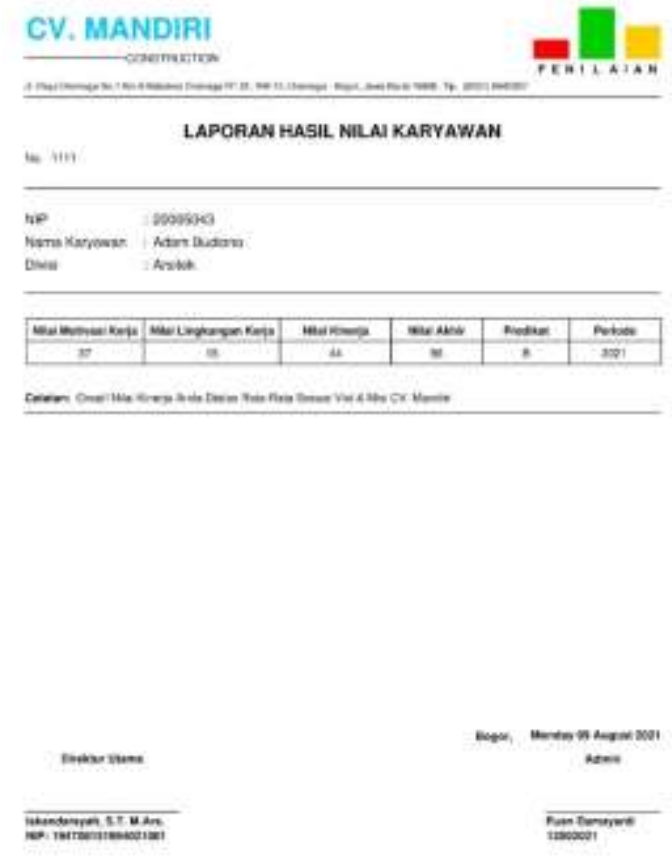

Gambar 16. Tampilan Layar Laporan Hasil Nilai Karyawan

Pada tampilan diatas terdapat laporan hasil nilai karyawan, dimana tampilan ini akan menampilkan laporan hasil nilai karyawan secara indivu yang telah diproses.

\section{SIMPULAN DAN SARAN}

Dengan dibuatnya sistem aplikasi ini diharapkan dapat mempermudah sistem penilaian dalam menyimpan data dan menginput data untuk membuat laporan. Pada sistem aplikasi ini sudah tidak perlu lagi mencatat cara manual atau dengan menggunakan Microsoft Office Excel, tetapi hanya dengan menginput data pada aplikasi kedalam database sehingga akan mempermudah dalam pengerjaanya. Serta dapat memudahkan untuk memantau atau mengontrol data yang diolah dan diproses oleh aplikasi disimpan kedalam database pada penyimpanan internal, sehingga semua data tidak hilang dan memudahkan admin untuk melakukan tugasnya karena rancangan interface dari aplikasi yang dibuat sangat mudah untuk dioperasikan.

Diharapkan aplikasi ini bisa dijadikan refrensi bagi peneliti selanjutnya untuk dikembangkan. Aplikasi ini masih bersifat offline yang artinya tidak terkoneksi dengan internet sehingga mungkin dapat melibatkan pihak ketiga untuk melakukan pengebangan program.

\section{UCAPAN TERIMAKASIH}

Penelitian ini terlaksana dengan lancer berkat dukungan dari keluarga yang selalu mendokan, memotivasi dan mendukung secara materi maupun moril selama dalam masa perkuliahan dan penelitian berlangsung. Tidak lupa dukungan dari orang-orang terdekat, teman dan sahabat serta dosen pembimbing, rektor dan pihak-pihak terkait lainnya yang telah banyak membantu penulis.

\section{DAFTAR PUSTAKA}

Ainnisya, R. N., \& Susilowati, I. H. (2018). Pengaruh Penilaian Kinerja Terhadap Motivasi Kerja Karyawan Pada Hotel Cipta Mampang Jakarta Selatan. Widya Cipta.

Indrajani. (2015). Database Design (Case Study All in One). PT Elex Media Komputindo.

Madcoms. (2016). Sukses Membangun Toko Online dengan PHP \& MySQL. Andi.

Nofriadi. (2015). Java Fundamental Dengan Netbeans 8.0.2. DeePublish.

Romney, M. B. \& P. J. S. (2011). Accounting Information System 9th Edn. Dewi Fitriasari dan Deny Arnos Kwary.

Satzinger, J. B. (2012). System Analys and Design In A Changing World. Cengage Learning.

Sihombing, S., Gultom, R. S., \& S. S. (2015). Manajemen Sumber Daya Manusia Edisi Revisi. In Media.

Sukamto, R. M. S. (2015). Rekayasa Perangkat Lunak Struktur dan Berorientasi Objek. Informatika.

Suyanto. (2015). Pemrograman Java: Pengenalan Java. Jurnal Komputer.

Wibawanto. (2017). Desain dan Pemrograman Multimedia Pembelajaran Interaktif. Cerdas Ulet Kreatif. 